Article

\title{
Synthesis of Antibacterial Nisin-Peptoid Hybrids Using Click Methodology
}

\author{
Hannah L. Bolt ${ }^{1,+}$ (i), Laurens H. J. Kleijn ${ }^{2,+}$, Nathaniel I. Martin ${ }^{2, *}$ (i) and Steven L. Cobb ${ }^{1, *}$ \\ 1 Center for Global Infectious Diseases, Department of Chemistry, Durham University, South Road, \\ Durham DH1 3LE, UK; bolth@medimmune.com \\ 2 Department of Medicinal Chemistry and Chemical Biology, Utrecht Institute for Pharmaceutical Sciences, \\ Utrecht University, Universiteitsweg 99, 3584 CG Utrecht, The Netherlands; 1.h.j.kleijn@uu.nl \\ * Correspondence: n.i.martin@uu.nl (N.I.M.); s.l.cobb@durham.ac.uk (S.L.C.) \\ + These authors contributed equally to this work.
}

Received: 31 May 2018; Accepted: 21 June 2018; Published: 28 June 2018

\begin{abstract}
Antimicrobial peptides and structurally related peptoids offer potential for the development of new antibiotics. However, progress has been hindered by challenges presented by poor in vivo stability (peptides) or lack of selectivity (peptoids). Herein, we have developed a process to prepare novel hybrid antibacterial agents that combine both linear peptoids (increased in vivo stability compared to peptides) and a nisin fragment (lipid II targeting domain). The hybrid nisin-peptoids prepared were shown to have low micromolar activity (comparable to natural nisin) against methicillin-resistant Staphylococcus aureus.
\end{abstract}

Keywords: peptoids; peptoid-peptide hybrid; nisin; antibacterial; alkyne-azide click reactions

\section{Introduction}

The rapid emergence of antibiotic resistance against commonly used frontline treatments poses a serious threat to global health and has emphasized the need for novel antimicrobials to be developed. This urgency is highlighted by increasing academic and industrial interest in the field and the establishment of enterprises such as the 2015 Ross Fund and the $10 \times$ '20 Initiative both of which encourage the delivery of new antimicrobial drug classes [1,2].

Nisin is a polycyclic peptide produced by several strains of the Gram-positive bacterium Lactococcus lactis and is an antimicrobial with nanomolar activity against other Gram-positive bacteria [3,4]. Due to its potent antibacterial activity and negligible toxicity, nisin (Figure 1) is frequently used as a food preservative and it provides a potential scaffold for the development of novel antibacterial agents $[3,4]$. Nisin contains five lanthione bridges which help impart a conformation that is key to its antibacterial properties [5,6]. In particular the A/B ring system at nisin's N-terminus has been shown to bind to lipid II, which is a crucial membrane component used in bacterial cell wall synthesis. Following lipid II binding, nisin can insert into the bacterial plasma membrane and create pores that cause cell leakage ultimately leading to cell death [5,7-12].

Given its selective mode of action, nisin provides an excellent starting point for the design of new antibiotics. However, due to nisin's peptide-based structure, the clinical development of the full-length peptide sequence remains challenging. Specifically, the high susceptibility of nisin towards proteolytic degradation in vivo has presented a major hurdle in its use as a general antibiotic $[10,13]$. Efforts to overcome stability issues via the total chemical synthesis or semi-synthesis of nisin analogues with improved properties have only had limited success [14-16]. 


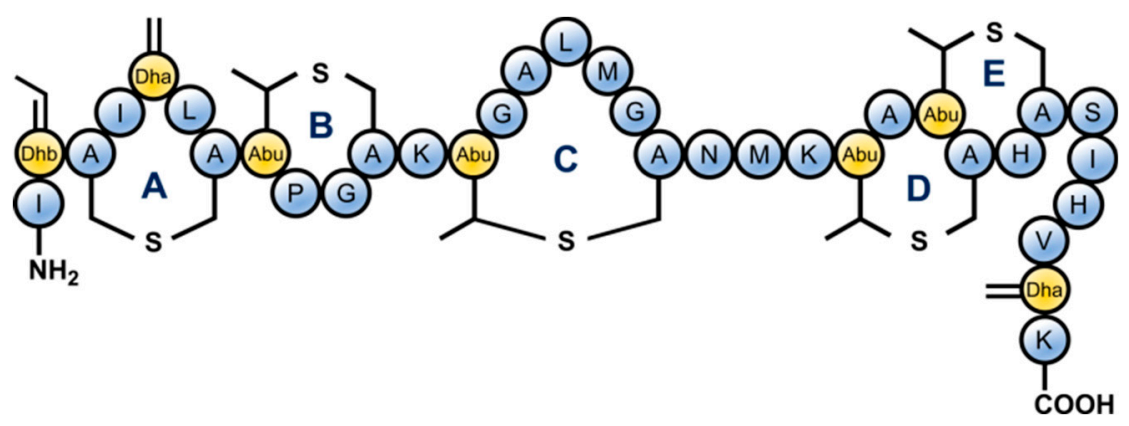

Figure 1. The structure of nisin. Classified as a lantibiotic due to the presence of unusual lanthionine rings in its structure, nisin also contains unsaturated amino acids introduced by posttranslational modifications: $\mathrm{Dhb}=$ dehydrobutyrine, $\mathrm{Dha}=$ dehydroalanine and $\mathrm{Abu}=$ aminobutyric acid.

Early studies in the area demonstrated that C-terminally truncated nisin peptides that still contain an intact $\mathrm{A} / \mathrm{B}$ ring system (nisin ${ }^{\mathrm{A} / \mathrm{B}}$ ) can still display low antibacterial activity [17]. The aforementioned results, led to numerous truncated nisin peptides being biologically evaluated, including recently promising semi-synthetic nisin-lipopeptides [9].

A strategy that is more commonly being utilized to stabilize peptide-based therapeutics is the synthesis of stable peptidomimetics such as peptoids ( $N$-substituted glycines) (Figure 2) [18-20]. Peptoids have shown activity as antibacterial [21-28], antifungal [29-31] and antiparasitic [32-35] compounds and most importantly they display increased resistance to protease action compared to $\alpha$-peptides [31,36]. In particular, peptoids have demonstrated antibacterial properties against a range of clinically relevant Gram negative and Gram positive bacteria, with activities that equal or surpass those achieved by many antimicrobial peptides (AMPs) [21-28]. Peptoids are also suspected to disrupt cell membranes non-specifically to achieve their antimicrobial effect, with similar modes of actions to simple AMPs [21,37]. Given this, peptoids display activity against many drug-resistant bacteria.

peptide<smiles>[R7]C([Y6])C(=O)NC([R])C(=O)NC([R])C(=O)NCC</smiles>

Susceptible to proteases Low bioavailability peptoid<smiles>[R]N([Y])CC(=O)N([R])CC(=O)N([R])CC(=O)O</smiles>

High biostability Longer lifetime in vivo

Figure 2. Representative structure of the backbone of a peptide compared to a peptoid. In peptoids, the side chain ' $R$ ' is moved to the nitrogen of the amide backbone, causing a substantial increase in chemical and biological stability.

Building on from this, we wished to investigate whether we could prepare semi-synthetic nisin analogues (e.g., peptide-peptoid hybrids) with comparable antibacterial activity to full-length nisin. To this end, we report a new class of peptide-peptoid hybrids that could be used in the development of novel antimicrobials. By linking short linear peptoids with the truncated nisin ${ }^{\mathrm{A} / \mathrm{B}}$ ring fragment, we were able to access molecules that have similar antibacterial activity against methicillin-resistant S. aureus compared to full-length nisin.

\section{Results and Discussion}

$\mathrm{Nisin}^{\mathrm{A} / \mathrm{B}}$ is obtained from the chemo-enzymatic degradation of full-length nisin [38] and this fragment can then be modified at the $C$ terminus by addition of an azide functionality [9]. The azide provides a convenient handle for ligation to alkynes via a copper-catalyzed click cycloaddition [39]. 
The click reaction between an azide and a terminal alkyne is compatible with a range of conditions, tolerates a broad range of chemical functionalities and provides a robust strategy for chemical ligations. Furthermore, as an isostere of the amide bond, the triazole formed by click reactions provides a biocompatible linker that readily associates with biological targets through hydrogen bonding and dipole interactions [39]. Additionally, the copper (I)-catalyzed click reaction can be performed under aqueous conditions at room temperature, so is well suited for use with peptide-based reagents [40]. For these reasons, the copper-catalyzed click reaction is ideal for the ligation of azide-functionalzsed nisin with terminal alkynyl peptoid sequences [41].

Two linear peptoid sequences (peptoid $\mathbf{1 a} \quad$ (NaeNspeNspe) $_{4}$ and $\mathbf{1 b}$ $\left.[(N L y s N p f b N p f b)(N L y s N s p e N s p e)]_{2}\right)$ were chosen as they had shown promising antibacterial activities with MICs below $2 \mu \mathrm{M}$ against S. aureus. Peptoids $\mathbf{1 a}$ and $\mathbf{1 b}$ are both 15 residues in length; i.e., the 12 residue parent sequence followed by two additional Nspe monomers to lengthen the chain between the last cationic residue and the $\mathrm{N}$ terminal Nprp

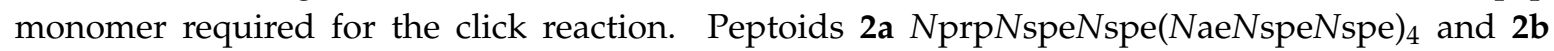
$N$ prpNspeNspe[(NLysNpfbNpfb)(NLysNspeNspe) $]_{2}$ were prepared via the submonomer procedure for the solid phase synthesis of peptoids, which utilizes successive acylation and displacement cycles (see Scheme 1). An alkyne tail was added to the sequence using propargylamine (Nprp) under standard coupling conditions [34,42,43]. Peptoids $\mathbf{2 a}$ and $\mathbf{2} \mathbf{b}$ were then cleaved from the resin and purified by RP-HPLC prior to the click reactions being performed.

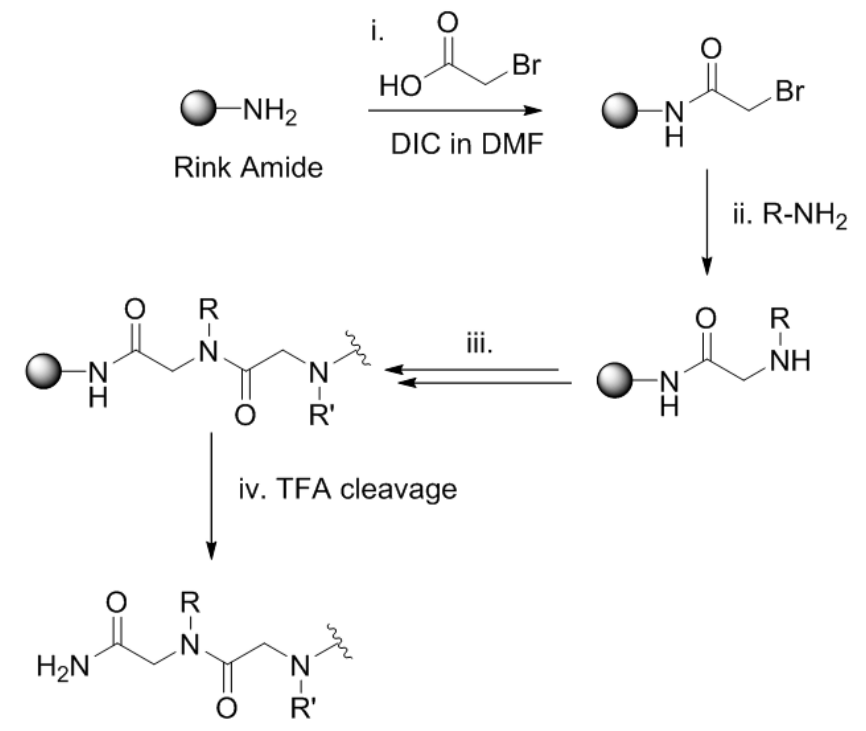

Scheme 1. Scheme to show the solid-phase, submonomer synthesis of peptoids: (i) acylation using bromoacetic acid and DIC in DMF, 20 min, RT; (ii) displacement with primary amine, $1.5 \mathrm{M}, \mathrm{RT}, 60$ min; (iii) repeated acylation and displacement to complete sequence; (iv) acidic TFA cleavage and deprotection of peptoid.

Nisin (3) was digested using trypsin and the fragment containing the A/B ring system (4) isolated by preparative HPLC. The $\operatorname{nisin}^{\mathrm{A} / \mathrm{B}}$ was then coupled to azidopropylamine and a second RP-HPLC purification undertaken to yield the truncated nisin with an azide linker (compound 5 in Scheme 2) [9].

Ligation of nisin ${ }^{\mathrm{A} / \mathrm{B}}$-azide and the alkyne-tagged peptoids was carried out under microwave irradiation using a copper(I)-catalyzed 'click' cycloaddition. The active $\mathrm{Cu}(\mathrm{I})$ catalyst is generated from the $\mathrm{Cu}(\mathrm{II})$ salt using sodium ascorbate as a reducing agent and with Tris[(1-benzyl-1H-1,2,3-triazol-4-yl)methyl]amine (TBTA) as a $\mathrm{Cu}(\mathrm{I})$ stabilizing ligand to cleanly afford the expected triazole product $[39,40,44]$. Completion of the click reaction was observed via LC-MS after $20 \mathrm{~min}$ microwave heating at $80^{\circ} \mathrm{C}$. Coupling times were limited to $20 \mathrm{~min}$ to avoid unwanted side 
reactions (i.e., Dha cyclization or lactamization) as previously described [9]. Following a final RP-HPLC purification, the expected conjugates $(\mathbf{6} \mathbf{a}$ and $\mathbf{6 b}$ ) were obtained in suitable purity for biological testing. Full methods and the characterization of $\mathbf{6 a}$ and $\mathbf{6} \mathbf{b}$ can be found in the Supplementary Materials.

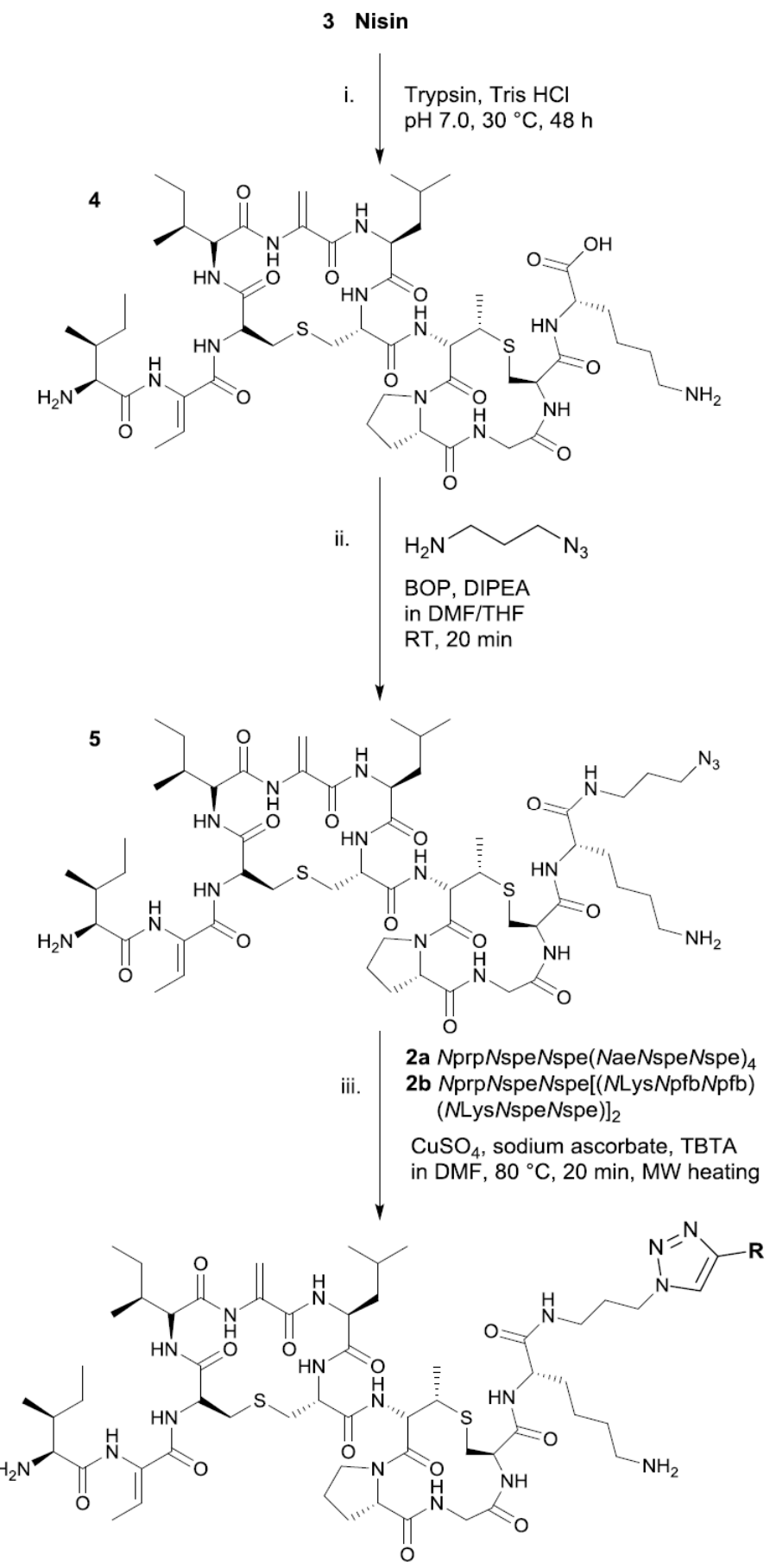

6a where $\mathbf{R}=\mathrm{NspeNspe}(\mathrm{NaeNspeNspe})_{4}$

6b $\quad \mathbf{R}=N$ speNspe $[(N \text { Lys } N p f b N p f b)(N L y s N \text { speNspe })]_{2}$

Scheme 2. Semi-synthesis of nisin ${ }^{\mathrm{A} / \mathrm{B}}$-peptoid hybrids using (i) digestion of nisin to the nisin ${ }^{\mathrm{A} / \mathrm{B}}$ ring; (ii) addition of azide functionality to nisin ${ }^{\mathrm{A} / \mathrm{B}}$; (iii) $\mathrm{Cu}(\mathrm{I})$ catalyzed click reaction with alkyne functionalized peptoid sequences. 
The antibacterial activity of the nisin-peptoid conjugates $\mathbf{6 a}$ and $\mathbf{6} \mathbf{b}$ were determined against methicillin-resistant Staphylococcus aureus USA 300; the predominant strain associated with community-acquired MRSA infection in the United States [45] (see Table 1). The minimum inhibitory concentrations (MICs) were calculated and compared to the peptide antibiotic vancomycin 7 and full-length nisin (3).

Table 1. Biological evaluation of peptide-peptoid conjugates and other fragments for comparison against methicillin-resistant S. aureus 300. Peptoids and peptide-peptoid hybrids show potent antibacterial action.

\begin{tabular}{|c|c|c|c|c|}
\hline & \multirow{2}{*}{ Sequence } & \multirow{2}{*}{$\begin{array}{c}\text { MIC }(\mu \mathrm{M}) \\
\text { S. aureus (USA300) }\end{array}$} & \multicolumn{2}{|c|}{$\mathrm{ED}_{50}(\mu \mathrm{M})$} \\
\hline & & & HaCaT & HepG2 \\
\hline 7 & Vancomycin & 1 & & \\
\hline 3 & Nisin & 5 & & \\
\hline 4 & Nisin[1-12] & $>100$ & & \\
\hline 5 & Nisin[1-12]-azide & 26 & & \\
\hline $1 \mathbf{a}$ & $(\text { NaeNspeNspe })_{4}$ & 2 & 26 & 15 \\
\hline $1 b$ & {$[(N L y s N p f b N p f b)(N L y s N s p e N s p e)]_{2}$} & $2-4$ & 53 & 18 \\
\hline $2 \mathbf{a}$ & NprpNspeNspe $(\text { NaeNspeNspe })_{4}$ & 4 & 20 & 12 \\
\hline $2 b$ & NprpNspeNspe[(NLysNpfbNpfb)(NLysNspeNspe) $]_{2}$ & $4-7$ & 15 & 17 \\
\hline $6 \mathbf{a}$ & Nisin[1-12]-NspeNspe $(N a e N s p e N s p e)_{4}$ & $5-10$ & 24 & 15 \\
\hline $6 b$ & Nisin[1-12]-NspeNspe[(NLysNpfbNpfb)(NLysNspeNspe) $]_{2}$ & $9-18$ & 22 & 23 \\
\hline
\end{tabular}

The parent peptoids without an alkyne linker demonstrated excellent activity against the methicillin-resistant $S$. aureus, with $\mathbf{1 a}$ and $\mathbf{1 b}$ displaying MICs of $2 \mu \mathrm{M}$ and $2-4 \mu \mathrm{M}$ respectively. Interestingly, simply functionalizing these peptoid sequences with an N-terminal alkyne reduces their activity by approximately a factor of $2(2 \mathbf{a}, 4 \mu \mathrm{M}$ and $2 \mathbf{b}, 4-7 \mu \mathrm{M})$. The nisin-peptoid hybrids $6 \mathbf{a}$ and $\mathbf{6 b}$ also show diminished antibacterial activity compared to the unconjugated peptoids (1a and $\mathbf{1 b})$. When comparing $\mathbf{6 a}$ to $\mathbf{1 a}$, the nisin-peptoid conjugate is approximately five-fold less active than the parent peptoid (i.e., MIC 5-10 $\mu \mathrm{M}$ compared to $2 \mu \mathrm{M}$ ) and this reduction in activity is similarly seen when comparing peptoid $\mathbf{6 b}$ and $\mathbf{1 b}$ (MIC 9-18 $\mu \mathrm{M}$ vs. 2-4 $\mu \mathrm{M}$ ). However, despite the reduction in activity compared to the peptoids alone, the MIC values for $\mathbf{6 a}$ and $\mathbf{6 b}$ are still in the low micromolar range against a drug resistant bacterium. In addition, 6a has a MIC similar to that of full-length nisin (3), and one that is considerably better than truncated nisin[1-12] (4).

In order to ascertain whether the decreased activity displayed by the nisin-peptoid conjugates (when compared to their parent peptoid sequences) was accompanied by a beneficial reduction in toxicity, cytotoxicity assays were performed against HaCaT keratinocytes and epithelial HepG2 cells. Results for this testing can be found in the ESI and the data obtained shows that the peptoid sequences with the $\mathrm{N}$ terminal alkyne ( $\mathbf{2} \mathbf{a}$ and $\mathbf{2} \mathbf{b})$ were the most cytotoxic to both mammalian cell lines tested $\left(\mathrm{ED}_{50}\right.$ values of $<20 \mu \mathrm{M}$ ). The nisin-conjugated peptoid sequences $\mathbf{6 a}$ and $\mathbf{6} \mathbf{b}$ were found to be moderately cytotoxic to both mammalian cell lines tested (e.g., ED 50 values of $22 \mu \mathrm{M}$ and $24 \mu \mathrm{M}$ against $\mathrm{HaCaT}$ for $6 \mathbf{a}$ and $\mathbf{6 b}$ respectively). The $\mathrm{ED}_{50}$ values obtained also showed that the nisin-peptoid hybrids (6a and $\mathbf{6 b}$ ) have either a similar level or increased toxicity to the HaCaT cells compared to the parent peptoids $\mathbf{1 a}$ and $\mathbf{1 b}$ (e.g., $\mathrm{ED}_{50}$ values of $26 \mu \mathrm{M}$ and $53 \mu \mathrm{M}$ against HaCaT for $\mathbf{1 a}$ and $\mathbf{1 b}$ respectively).

\section{Materials and Methods}

\subsection{Linear Peptoid Synthesis (1a, $\mathbf{1 b}, \mathbf{2 a}$ and $\mathbf{2 b})$}

Fmoc-protected Rink Amide resin $\left(0.1 \mathrm{mmol}\right.$, loading $\left.0.82 \mathrm{mmol} \mathrm{g}^{-1}\right)$ was swollen in DMF (at least $1 \mathrm{~h}$, overnight preferred, at room temperature) in a $20 \mathrm{~mL}$ polypropylene syringe fitted with two polyethylene frits. The resin was deprotected with piperidine ( $20 \%$ in DMF v/v, $2 \times 20 \mathrm{~min})$ and washed with DMF $(3 \times 2 \mathrm{~mL})$. The resin was treated with bromoacetic acid $(1 \mathrm{~mL}, 0.6 \mathrm{M}$ in DMF $)$ and 
DIC $(0.20 \mathrm{~mL}, 50 \% v / v$ in DMF) for $20 \mathrm{~min}$ at room temperature at $400 \mathrm{rpm}$. The resin was washed with DMF $(3 \times 2 \mathrm{~mL})$, before the desired amine sub-monomer was added $(1 \mathrm{~mL}, 0.8-2.0 \mathrm{M}$ in DMF) and allowed to react for $60 \mathrm{~min}$ at room temperature on the shaker. The resin was again washed with DMF $(3 \times 2 \mathrm{~mL})$ and the bromoacetylation and amine displacement steps were repeated until the final submonomer had been added and the desired peptoid sequence had been obtained. The resin was shrunk in diethyl ether to remove DMF in preparation for cleavage. Final cleavage from resin was achieved using TFA (95\%), $\mathrm{H}_{2} \mathrm{O}(2.5 \%)$ and TIPS (2.5\%). For test cleaves approximately $1 \mathrm{~mL}$ of the cleavage cocktail was used and for cleavage from $100 \mathrm{mg}$ resin, approximately $4 \mathrm{~mL}$ of the cleavage cocktail was added. The resin was then placed on the shaker at $400 \mathrm{rpm}$ for $45 \mathrm{~min}$ and the resin removed by filtration. The cleavage cocktail was removed in vacuo, the crude product precipitated in diethyl ether $(45 \mathrm{~mL})$ and the precipitate retrieved by centrifuge for $15 \mathrm{~min}$ at 5000 rpm. The ether phase was decanted, the crude product dissolved in a mixture of acidified $\mathrm{H}_{2} \mathrm{O}$ and $\mathrm{MeCN}$ and lyophilized. Crude peptoid sequences were purified using RP-HPLC prior to ligation with $\operatorname{nisin}^{\mathrm{A} / \mathrm{B}}$. For further details see the Supplementary Materials.

\subsection{Amide-Coupled Azide-Nisin ${ }^{A / B}$ (5)}

Nisin (600 mg, $0.18 \mathrm{mmol})$ was dissolved in $250 \mathrm{~mL}$ Tris buffer $(25 \mathrm{mmol}$, NaOAc, $5 \mathrm{mmol}$ Tris acetate, $5 \mathrm{mmol} \mathrm{CaCl}_{2}, \mathrm{pH} 7.0$ ) and the solution cooled on ice for $15 \mathrm{~min}$. Trypsin (50 mg) was added and stirred at room temperature for $15 \mathrm{~min}$. The mixture was then heated to $30{ }^{\circ} \mathrm{C}$ for $16 \mathrm{~h}$, then another $50 \mathrm{mg}$ of trypsin was added and after an additional $24 \mathrm{~h}$ the reaction was complete by HPLC. The reaction was acidified with $\mathrm{HCl}(1 \mathrm{M})$ to $\mathrm{pH} 4.0$ and solvents removed in vacuo. The nisin fragment was isolated by preparative HPLC and product fractions lyophilized to obtain a white powder $(80 \mathrm{mg}$, $39 \%)$. Nisin ${ }^{\mathrm{A} / \mathrm{B}}$ was dissolved in DMF (240 $\left.\mu \mathrm{L}\right)$. BOP (2 eq.), DIPEA (4 eq.) and azidopropylamine (50 eq.) were added. The reaction was stirred for $20 \mathrm{~min}$ then quenched in the appropriate buffer $(95 \%$ $\mathrm{H}_{2} \mathrm{O}, 5 \% \mathrm{MeCN}, 0.1 \% \mathrm{TFA}, 4 \mathrm{~mL}$ ). The solution was centrifuged for $5 \mathrm{~min}$ at $5000 \mathrm{rpm}$ to remove any insoluble material and the supernatant was purified by RP-HPLC. Relevant fractions were collected and analyzed to yield the pure Nisin ${ }^{\mathrm{A}}$ B -azide. For further details see the Supplementary Materials.

\subsection{Click Protocol of Alkyne-Peptoids with Nisin ${ }^{A / B}$-Azide (6a, 6b)}

$10 \times$ stock solutions of $\mathrm{CuSO}_{4}\left(16.2 \mu \mathrm{mol}, 2.59 \mathrm{mg}\right.$ in $\left.1 \mathrm{~mL} \mathrm{H}{ }_{2} \mathrm{O}\right), 10 \times$ sodium ascorbate $(32.4 \mu \mathrm{mol}$, $6.42 \mathrm{mg}$ in $\left.1 \mathrm{~mL} \mathrm{H} \mathrm{H}_{2} \mathrm{O}\right)$ and $10 \times$ TBTA $(4.1 \mu \mathrm{mol}, 2.18 \mathrm{mg}$ in $1 \mathrm{~mL}$ DMF) were freshly prepared. Nisin ${ }^{\mathrm{A} / \mathrm{B}}$-azide (1 eq., $8.1 \mu \mathrm{mol}, 10 \mathrm{mg}$ ) was dissolved in $200 \mu \mathrm{L}$ DMF and added to the peptoid in the microwave reaction vessel (1 eq., $8.1 \mu \mathrm{mol}) .100 \mu \mathrm{L}$ of the $\mathrm{CuSO}_{4}$ solution $(0.2$ eq., $1.62 \mu \mathrm{mol})$, $100 \mu \mathrm{L}$ of sodium ascorbate stock (0.4 eq., $3.24 \mu \mathrm{mol})$ and $100 \mu \mathrm{L}$ of the TBTA solution (0.05 eq., $0.41 \mu \mathrm{mol})$ were added. The vessel was sealed and heated under microwave power for $20 \mathrm{~min}$ at $80{ }^{\circ} \mathrm{C}$. The reaction mixture was diluted in the appropriate buffer $\left(95 \% \mathrm{H}_{2} \mathrm{O}, 5 \% \mathrm{MeCN}, 0.1 \% \mathrm{TFA}\right.$, $4 \mathrm{~mL})$ and purified by RP-HPLC on a Reprospher $100 \mathrm{C} 8$ - or C18-Aqua column $(10 \mu \mathrm{m} \times 250 \mathrm{~mm} \times$ $20 \mathrm{~mm}$ ) at a flow rate of $6 \mathrm{~mL} \mathrm{~min}^{-1} ; \lambda=214 \mathrm{~nm}$; linear gradient elution $20-80 \%$ solvent B over $120 \mathrm{~min}$ (where $\mathrm{A}=95 \% \mathrm{H}_{2} \mathrm{O}, 5 \% \mathrm{MeCN}, 0.1 \% \mathrm{TFA} ; \mathrm{B}=95 \% \mathrm{MeCN}, 5 \% \mathrm{H}_{2} \mathrm{O}, 0.1 \% \mathrm{TFA}$ ). Relevant fractions were combined and lyophilized from 1:1 $\mathrm{H}_{2} \mathrm{O}:{ }^{t} \mathrm{BuOH}$ mixture to yield purified peptoid-peptide conjugates as a white powder.

\subsection{MIC Determination}

Compound stocks in DMSO were diluted 50× in cation-adjusted Mueller Hinton broth (CAMHB; $10 \mathrm{mg} \mathrm{L}^{-1} \mathrm{Mg}^{2+}, 50 \mathrm{mg} \mathrm{L}{ }^{-1} \mathrm{Ca}^{2+}$ ) and serially diluted in polypropylene 96-well plates to reach a volume of $50 \mu \mathrm{L}$ per well. MRSA USA300 was grown in TSB until the exponential growth phase $\left(\mathrm{OD}_{600}=0.5\right)$ before dilution in CAMHB and addition to the wells $(50 \mu \mathrm{L})$ to reach a final CFU concentration of $5 \times 10^{5} \mathrm{~mL}^{-1}$. After overnight incubation $\left(35^{\circ} \mathrm{C}, 250 \mathrm{RPM}\right)$ the plates were inspected visually for growth. Experiments were carried out in duplicate. 


\section{Conclusions}

In conclusion, an efficient and direct methodology that allows the semi-synthesis of novel nisin-peptoid hybrids ( $6 \mathbf{a}$ and $\mathbf{6 b}$ ) has been developed. The key step in the process involves the use of a $\mathrm{Cu}(\mathrm{I})$ catalyzed click reaction. $\mathbf{6 a}$ and $\mathbf{6} \mathbf{b}$ were found to have low micromolar activity against methicillin-resistant $S$. aureus (USA300) with MIC values of $5 \mu \mathrm{M}$ and $9 \mu \mathrm{M}$ respectively. This antibacterial activity is similar to full-length nisin (3) (MIC $5 \mu \mathrm{M}$ ), and is considerably better than truncated nisin[1-12] (4) MIC > $100 \mu \mathrm{M}$. Given the aforementioned results the primary aim of the work to prepare semi-synthetic nisin analogues with comparable activity to full-length nisin has been achieved. Building on from this proof of concept study we are now expanding the library of nisin-peptoid hybrids, and, looking to investigate in more detail whether this class peptide-peptoid hybrid displays a lipid II targeting mode of action.

Supplementary Materials: Full materials, synthesis and purification methods, biological protocols, and characterization data for all compounds synthesized are available online.

Author Contributions: S.L.C. and N.I.M. conceived, designed and managed the project. H.L.B. and L.H.J.K. contributed equally to the experimental work. All authors contributed to the analysis of the results and the writing of the manuscript.

Acknowledgments: We wish to thank the Engineering and Physical Sciences Research Council (grant number EP/L504762/1, HLB) for support.

Conflicts of Interest: The authors declare no conflict of interest.

\section{References and Note}

1. Department for International Development and Department of Health. United Kingdom, 2015.

2. Infectious Diseases Society of America. The $10 \times$ '20 Initiative: Pursuing a global commitment to develop 10 new antibacterial drugs by 2020. Clin. Infect. Dis. 2010, 50, 1081-1083.

3. Kramer, N.E.; Smid, E.J.; Kok, J.; de Kruijff, B.; Kuipers, O.P.; Breukink, E. Resistance of Gram-positive bacteria to nisin is not determined by lipid II levels. FEMS Microbiol. Lett. 2004, 239, 157-161. [CrossRef] [PubMed]

4. Martin, N.I.; Breukink, E. The expanding role of lipid II as a target for lantibiotics. Future Microbiol. 2007, 2, 513-525. [CrossRef] [PubMed]

5. Arnison, P.G.; Bibb, M.J.; Bierbaum, G.; Bowers, A.A.; Bugni, T.S.; Bulaj, G.; Camarero, J.A.; Campopiano, D.J.; Challis, G.L.; Clardy, J.; et al. Ribosomally synthesized and post-translationally modified peptide natural products: Overview and recommendations for a universal nomenclature. Nat. Prod. Rep. 2013, 30, 108-160. [CrossRef] [PubMed]

6. Gross, E.; Morell, J.L. Structure of nisin. J. Am. Chem. Soc. 1971, 93, 4634-4635. [CrossRef] [PubMed]

7. Zhou, L.; van Heel, A.J.; Montalban-Lopez, M.; Kuipers, O.P. Potentiating the Activity of Nisin against Escherichia coli. Front. Cell Dev. Biol. 2016, 4, 7. [CrossRef] [PubMed]

8. Arnusch, C.J.; Bonvin, A.M.J.J.; Verel, A.M.; Jansen, W.T.M.; Liskamp, R.M.J.; de Kruijff, D.; Pieters, R.J.; Breukink, E. The vancomycin-nisin (1-12) hybrid restores activity against vancomycin resistant Enterococci. Biochemistry 2008, 47, 12661-12663. [CrossRef] [PubMed]

9. Koopmans, T.; Wood, T.M.; t'Hart, P.; Kleijn, L.H.J.; Hendrickx, A.P.A.; Willems, R.J.L.; Breukink, E.; Martin, N.I. Semisynthetic Lipopeptides Derived from Nisin Display Antibacterial Activity and Lipid II Binding on Par with That of the Parent Compound. J. Am. Chem. Soc. 2015, 137, 9382-9389. [CrossRef] [PubMed]

10. Breukink, E.; Wiedemann, I.; van Kraaij, C.; Kuipers, O.P.; Sahl, H.G.; de Kruijff, B. Use of the cell wall precursor lipid II by a pore-forming peptide antibiotic. Science 1999, 286, 2361-2364. [CrossRef] [PubMed]

11. Breukink, E.; de Kruijff, B. Lipid II as a target for antibiotics. Nat. Rev. Drug Discov. 2006, 5, 321-332. [CrossRef] [PubMed]

12. Schneider, T.; Sahl, H.G. Lipid II and other bactoprenol-bound cell wall precursors as drug targets. Curr. Opin. Investig. Drug 2010, 11, 157-164. 
13. Van Heel, A.J.; Montalban-Lopez, M.; Kuipers, O.P. Evaluating the feasibility of lantibiotics as an alternative therapy against bacterial infections in humans. Expert Opin. Drug Metab. Toxicol. 2011, 7, 675-680. [CrossRef] [PubMed]

14. Ghalit, N.; Reichwein, J.F.; Hilbers, H.W.; Breukink, E.; Rijkers, D.T.S.; Liskamp, R.M.J. Synthesis of bicyclic alkene-/alkane-bridged nisin mimics by ring-closing metathesis and their biochemical evaluation as lipid II binders: Toward the design of potential novel antibiotics. ChemBioChem 2007, 8, 1540-1554. [CrossRef] [PubMed]

15. Slootweg, J.C.; Peters, N.; Quarles van Ufford, H.L.; Breukink, E.; Liskamp, R.M.J.; Rijkers, D.T. Semi-synthesis of biologically active nisin hybrids composed of the native lanthionine ABC-fragment and a cross-stapled synthetic DE-fragment. Bioorg. Med. Chem. 2014, 22, 5345-5353. [CrossRef] [PubMed]

16. Ross, A.C.; McKinnie, S.M.K.; Vederas, J.C. The Synthesis of Active and Stable Diaminopimelate Analogues of the Lantibiotic Peptide Lactocin S. J. Am. Chem. Soc. 2012, 134, 2008-2011. [CrossRef] [PubMed]

17. Rink, R.; Wierenga, J.; Kuipers, A.; Kluskens, L.D.; Driessen, A.J.; Kuipers, O.P.; Moll, G.N. Dissection and Modulation of the Four Distinct Activities of Nisin by Mutagenesis of Rings A and B and by C-Terminal Truncation. Appl. Environ. Microbiol. 2007, 73, 5809-5816. [CrossRef] [PubMed]

18. Simon, R.J.; Kania, R.S.; Zuckermann, R.N.; Huebner, V.D.; Jewell, D.A.; Banville, S.; Ng, S.; Wang, L.; Rosenberg, S.; Marlowe, C.K.; et al. Peptoids: A modular approach to drug discovery. Proc. Natl. Acad. Sci. USA 1992, 89, 9367-9371. [CrossRef] [PubMed]

19. Patch, J.A.; Kirshenbaum, K.; Seurynck, S.L.; Zuckermann, R.N.; Barron, A.E. Pseudopeptides in Drug Development; Nielsen, P.E., Ed.; Wiley-VCH: Weinheim, Germany, 2004; p. 1.

20. Zuckermann, R.N.; Kodadek, T. Peptoids as potential therapeutics. Curr. Opin. Mol. Ther. 2009, 11, $299-309$. [PubMed]

21. Chongsiriwatana, N.P.; Patch, J.A.; Czyzewski, A.M.; Dohm, M.T.; Ivankin, A.; Gidalevitz, D.; Zuckermann, R.N.; Barron, A.E. Peptoids that mimic the structure, function, and mechanism of helical antimicrobial peptides. Proc. Natl. Acad. Sci. USA 2008, 105, 2794-2799. [CrossRef] [PubMed]

22. Bolt, H.L.; Eggimann, G.A.; Jahoda, C.A.B.; Zuckermann, R.N.; Sharples, G.J.; Cobb, S.L. Exploring the links between peptoid antibacterial activity and toxicity. Med. Chem. Commun. 2017, 8, 886-896. [CrossRef]

23. Kapoor, R.; Eimerman, P.R.; Hardy, J.W.; Cirillo, J.D.; Contag, C.H.; Barron, A.E. Efficacy of antimicrobial peptoids against Mycobacterium tuberculosis. Antimicrob. Agents Chemother. 2011, 55, 3058-3062. [CrossRef] [PubMed]

24. Kapoor, R.; Wadman, M.W.; Dohm, M.T.; Czyzewski, A.M.; Spormann, A.M.; Barron, A.E. Antimicrobial Peptoids Are Effective against Pseudomonas aeruginosa Biofilms. Antimicrob. Agents Chemother. 2011, 55, 3054-3057. [CrossRef] [PubMed]

25. Olsen, C.A.; Ziegler, H.L.; Nielsen, H.M.; Frimodt-Moller, N.; Jaroszewski, J.W.; Franzyk, H. Antimicrobial, hemolytic, and cytotoxic activities of beta-peptoid-peptide hybrid oligomers: Improved properties compared to natural AMPs. ChemBioChem 2010, 11, 1356-1360. [CrossRef] [PubMed]

26. Huang, M.L.; Shin, S.B.Y.; Benson, M.A.; Torres, V.J.; Kirshenbaum, K. A comparison of linear and cyclic peptoid oligomers as potent antimicrobial agents. ChemMedChem 2012, 7, 114-122. [CrossRef] [PubMed]

27. Huang, M.L.; Benson, M.A.; Shin, S.B.Y.; Torres, V.J.; Kirshenbaum, K. Amphiphilic cyclic peptoids that exhibit antimicrobial activity by disrupting Staphylococcus aureus membranes. Eur. J. Org. Chem. 2013, 17, 3560-3566. [CrossRef]

28. Findlay, B.; Szelemej, P.; Zhanel, F.; Schweizer, F. Guanidylation and Tail Effects in Cationic Antimicrobial Lipopeptoids. PLoS ONE 2012, 7, e41141. [CrossRef] [PubMed]

29. Ryge, T.S.; Frimodt-Moller, N.; Hansen, P.R. Antimicrobial activities of twenty lysine-peptoid hybrids against clinically relevant bacteria and fungi. Chemotherapy 2008, 54, 152-156. [CrossRef] [PubMed]

30. Uchida, M.; McDermott, G.; Wetzler, M.; Le Gros, M.A.; Myllys, M.; Knoechel, C.; Barron, A.E.; Larabell, C.A. Soft X-ray tomography of phenotypic switching and the cellular response to antifungal peptoids in Candida albicans. Proc. Natl. Acad. Sci. USA 2009, 106, 19375-19380. [CrossRef] [PubMed]

31. Luo, Y.; Bolt, H.L.; Eggimann, G.A.; Mc Auley, D.F.; Mc Mullan, R.; Curran, T.; Zhou, M.; Jahoda, C.A.B.; Cobb, S.L.; Lundy, F.T. Peptoid efficacy against polymicrobial biofilms determined using propidium monoazide-modified quantitative PCR. ChemBioChem 2017, 18, 111-118. [CrossRef] [PubMed] 
32. Vedel, L.; Bonke, G.; Foged, C.; Ziegler, H.; Franzyk, H.; Jaroszewski, J.W.; Olsen, C.A. Antiplasmodial and prehemolytic activities of alpha-peptide-beta-peptoid chimeras. ChemBioChem 2007, 8, 1781-1784. [CrossRef] [PubMed]

33. Eggimann, G.A.; Bolt, H.L.; Denny, P.W.; Cobb, S.L. Investigating the anti-leishmanial effects of linear peptoids. ChemMedChem 2015, 10, 233-237. [CrossRef] [PubMed]

34. Bolt, H.L.; Denny, P.W.; Cobb, S.L. An Efficient Method for the Synthesis of Peptoids with Mixed Lysine-type/Arginine-type Monomers and Evaluation of Their Anti-leishmanial Activity. J. Vis. Exp. 2016, 117, e54750. [CrossRef] [PubMed]

35. Bolt, H.L.; Eggimann, G.A.; Denny, P.W.; Cobb, S.L. Enlarging the chemical space of anti-leishmanials: A structure-activity relationship study of peptoids against Leishmania mexicana, a causative agent of cutaneous leishmaniasis. MedChemComm 2016, 7, 799-805. [CrossRef]

36. Miller, S.M.; Simon, R.J.; Ng, S.; Zuckermann, R.N.; Kerr, J.M.; Moos, W.H. Comparison of the Proteolytic Susceptibilities of Homologous L-Amino Acid, D-Amino Acid, and N-Substituted Glycine Peptide and Peptoid Oligomers. Drug Dev. Res. 1995, 35, 20-32. [CrossRef]

37. Mojsoska, B.; Jenssen, H. Peptides and Peptidomimetics for Antimicrobial Drug Design. Pharmaceuticals 2015, 8, 366-415. [CrossRef] [PubMed]

38. Chan, W.C.; Leyland, M.; Clark, J.; Dodd, H.M.; Lian, L.Y.; Gasson, M.J.; Bycroft, B.W.; Roberts, G.C. Structure-activity relationships in the peptide antibiotic nisin: Antibacterial activity of fragments of nisin. FEBS Lett. 1996, 390, 129-132. [CrossRef]

39. Rostovtsev, V.V.; Green, L.G.; Fokin, V.V.; Sharpless, K.B. A stepwise huisgen cycloaddition process: Copper(I)-catalyzed regioselective ligation of azides and terminal alkynes. Angew. Chem. Int. Ed. Engl. 2002, 41, 2596-2599. [CrossRef]

40. Tornoe, C.W.; Christensen, C.; Meldal, M. Peptidotriazoles on Solid Phase: [1-3]-Triazoles by Regiospecific Copper(I)-Catalyzed 1,3-Dipolar Cycloadditions of Terminal Alkynes to Azides. J. Org. Chem. 2002, 67, 3057-3064. [CrossRef] [PubMed]

41. Kolb, H.C.; Sharpless, K.B. The growing impact of click chemistry on drug discovery. Drug Discov. Today 2003, 8, 1128-1137. [CrossRef]

42. Bolt, H.L.; Cobb, S.L. A practical method for the synthesis of peptoids containing both lysine-type and arginine-type monomers. Org. Biomol. Chem. 2016, 14, 1211-1215. [CrossRef] [PubMed]

43. Zuckermann, R.N.; Kerr, J.M.; Kent, S.B.H.; Moos, W.H. Efficient method for the preparation of peptoids [oligo ( $N$-substituted glycines)] by submonomer solid-phase synthesis. J. Am. Chem. Soc. 1992, 114, 10646-10647. [CrossRef]

44. Chan, T.R.; Hilgraf, R.; Sharpless, K.B.; Fokin, V.V. Polytriazoles as Copper(I)-Stabilizing Ligands in Catalysis. Org. Lett. 2004, 6, 2853-2855. [CrossRef] [PubMed]

45. Margaret, C.; Eli, N.P.; Michael, Z.D. USA300 Methicillin-Resistant Staphylococcus aureus, United States, 2000-2013. Emerg. Infect. Dis. 2015, 21, 1973-1980.

Sample Availability: Samples of the compounds are available from the authors.

(C) 2018 by the authors. Licensee MDPI, Basel, Switzerland. This article is an open access article distributed under the terms and conditions of the Creative Commons Attribution (CC BY) license (http:/ / creativecommons.org/licenses/by/4.0/). 